\title{
Localization of 5S Gene Loci on Polytene Chromosomes of Glyptotendipes barbipes (Staeger) and Transcription of RNA from These Sites
}

\author{
Wu-Nan Wen ${ }^{1}$ and Donald R. Hague \\ Department of Biology, University of Oregon, Eugene, Oregon 97403, U.S.A.
}

Received August 6, 1977

Ribosomal 5S RNA (5S RNA) is transcribed from tandemly repeated sequences of the eucaryotic genome (Tartof and Perry 1970). Repetition of the genes for 5S RNA has permitted localization of these DNA sequences on the chromosomes of Drosophila melanogaster (Wimber and Steffensen 1970), Xenopus laevis (Pardue et al. 1973), Hela cells (Steffensen et al. 1974, Johnson et al. 1974), Glyptotendipes barbipes (Wen et al. 1974), Zea mays (Wimber et al. 1974), Taricha granulosa (Leon 1976), Chironomus tentans (Weislander et al. 1975) and Notophthalmus viridescens (Pukkila 1975) by in situ hybridization (Gall and Pardue 1969) with purified 5S RNA. An interesting result of these studies is the finding that the $5 \mathrm{~S}$ genes are often clustered in several different regions of the genome. For example, the 24,000 repeats of the genes in $X$. laevis are distributed on the telomeres of almost all of the 36 chromosomes of this organism (Pardue et al. 1973). The 5S genes in Hela cells are on chromosomes 1, 9 and 16 (Steffensen et al. 1974), and these same genes occupy four bands, $56 \mathrm{~F} 1-2$ and $56 \mathrm{~F} 6-7$, on chromosome $2 \mathrm{R}$ of $D$. melanogaster (Szabo 1974). In $N$. viridescens, 300,000 sequences coding for 5S RNA are located on the four or five non-homologous chromosomes (Hutchison and Pardue 1975, Pukkila 1975).

Are all the genes for 5S RNA at the several loci on these chromosomes active in all cell types throughout development? Evidence from sequence analysis of 5S RNA isolated from $X$. laevis suggests that this is not the case and that there is differential transcription of the genes for $5 \mathrm{~S}$ RNA. It has been shown that cultured somatic cells of $X$. laevis synthesize a 5S RNA which differs in base composition at seven sequence positions from the major 5S RNA synthesized in the oocyte (Brownlee et al. 1972, Wegnez et al. 1972, Ford and Southern 1973). In addition there are several distinct minor 5S RNAs detectable in the oocyte itself (Wegnez et al. 1972, Ford and Southern 1973). This implies that the repeated 5S genes in this organism are heterogenous. It remains to be shown that heterogeneity of 5S RNA is or is not a general feature among eucaryotic organisms with multiple $5 \mathrm{~S}$ loci, and if so, whether the $5 \mathrm{~S}$ genes comprising a particular locus are homogeneous or heterogeneous in sequence.

Results presented in a previous communication (Wen et al. 1974) indicate that there are probably several $5 \mathrm{~S}$ gene loci on chromosomes of G. barbipes. It was of

1 Present address: Institute of Biochemistry, College of Medicine, National Taiwan University, Taipei, Taiwan, R.O.C. 
interest, therefore, for us to determine if all these sites are active in specific cells of this organism. Salivary gland chromosomes are ideal for such a study because transcription can be visualized directly as chromosomal puffs, or can easily be detected by labeling cells with ${ }^{3} \mathrm{H}$-uridine and analyzing autoradiographs of the chromosomes. Furthermore, there are four larval instars during the development of $G$. barbipes, and if the activity of the several loci is stage-dependent, the salivary glands offer an easily manipulated, homogeneous system for tracing the cause of the change of activity in different cells.

We present evidence here confirming the presence of multiple $5 \mathrm{~S}$ sites on the chromosomes of $G$. barbipes and showing that multiple gene sites on the same chromosome may arise by chromosomal inversion. We also present data indicating probable differential transcription from the several $5 \mathrm{~S}$ loci on the polytene salivary gland chromosomes.

Materials and methods

\section{Animals}

Larvae of G. barbipes were collected either from sewage lagoons near Eugene, Oregon, or at Gavins Point National Fish Hatchery, Yankton, South Dakota. Animals from the latter source were kindly supplied by Mr. Dan B. Martin, Fisheries Research Biologist, U. S. Fish and Wildlife Service. D. melanogaster (Canton $\mathrm{S} \times$ Oregon $\mathrm{R}$ ) was cultured on cornmeal media for extraction of nucleic acids.

Preparation of ribosomal 5S RNA from D. melanogaster

All procedures were conducted at $4^{\circ} \mathrm{C}$. Mixed age adult flies were collected and freeze-dried. Approximately $10 \mathrm{~g}$ (dry weight) of flies were homogenized in $100 \mathrm{ml}$ of buffer: $50 \mathrm{mM}$ Tris- $\mathrm{HCl}(\mathrm{pH} 7.2), 7 \mathrm{mM}$ beta-mercaptoethanol, $100 \mathrm{mM}$ $\mathrm{KCl}, 6 \mathrm{mM} \mathrm{Mg}\left(\mathrm{C}_{2} \mathrm{H}_{3} \mathrm{O}_{2}\right)_{2}, 1 \mathrm{mM} \mathrm{Na} \mathrm{Na}_{2}$ EDTA, $1 \mathrm{mM}$ 1-phenyl-2-thiourea and $250 \mathrm{mM}$ sucrose. After homogenization, a further $80 \mathrm{ml}$ of buffer was added, and the ribosomes were prepared following the procedure of Pelley and Stafford (1970) with some modifications. The homogenate was centrifuged at $25,000 \times g$ for 30 minutes, and the buffer layer was decanted and recentrifuged at the same speed for 15 minutes. The final supernatant layer was transferred to polycarbonate centrifuge tubes of the Spinco Ti-60 rotor (Beckman Instruments, Inc., Palo Alto, Cal.). After two hours centrifugation at $40,000 \mathrm{rpm}$ the ribosomal pellet was removed and extracted using the procedures of Monier (1971) for preparation of 5S RNA. RNA was extracted with buffered phenol, purified through DEAEcellulose and fractionated by Sephadex G-100 column chromatography. Eightyfour $\mathrm{A}_{260}$ units of RNA were obtained after EDTA-cellulose chromatography, and this separated into three peaks on Sephadex G-100 (Fig. 1).

Analytical gel electrophoresis

Composite gels of $4 \%$ acrylamide and $0.5 \%$ agarose were used to analyze RNA fractions. Gels were prepared, run, stained with methylene blue and destained according to methods of Dingman and Peacock (1973). 


\section{Iodination of SS RNA of D. melanogaster}

Pooled RNA, characterized as $5 \mathrm{~S}$, was iodinated with carrier-free ${ }^{125}$ I-labelled RNA as described previously (Wen et al. 1974). Specific activity of the ${ }^{125}$ I-labelled RNA was calculated to be $9.62 \times 10^{6} \mathrm{dpm} / \mu \mathrm{g}$.

\section{In situ hybridization}

Five $\mu \mathrm{g}$ of ${ }^{125}$ I-labelled RNA were dissolved in $0.5 \mathrm{ml}$ of $2 \times \mathrm{SSC}$ buffer $(\mathrm{pH}$ 7.2) containing $50 \%$ formamide $(\mathrm{V} / \mathrm{V})$. Twenty $\mu \mathrm{l}$ of this solution were applied to each slide for in situ hybridization. The details of this procedure have also been described previously (Wen et al. 1974). However, in the present study, yeast 4S RNA from Calbiochem, Inc. (La Jolla, Cal.) was purified on benzoylated DEAEcellulose and was included in the annealing mixture to reduce non-specific binding of labelled molecules to the chromosomes.

\section{Labelling of salivary gland chromosomes with ${ }^{3} \mathrm{H}$-uridine}

Salivary glands from different larval instars of $G$. barbipes were removed from the organism, placed in Robert's CR-Medium (Robert 1971) and labelled with ${ }^{3} \mathrm{H}$ uridine $\left(40 \mathrm{Ci} / \mathrm{mole}, 200 \mu \mathrm{C} / \mathrm{ml}\right.$ Robert's CR-Medium) for 10 minutes at $18-22^{\circ} \mathrm{C}$. After incubation the glands were fixed in absolute ethanol and glacial acetic acid (3: $1 \mathrm{~V} / \mathrm{V})$, squashed, washed three times with cold $5 \%$ trichloroacetic acid, and dipped into Kodak NTB-2 emulsion diluted with an equal volume of water. Autoradiographs were exposed for various periods as indicated in figure legends. When $\alpha$-amanitin (Calbiochem, Inc.) was used to inhibit RNA polymerase activity, the salivary glands were incubated for 15 minutes in $\alpha$-amanitin dissolved in CRmedium before addition of ${ }^{3} \mathrm{H}$-uridine.

\section{Results}

\section{Preparation of 5S RNA from D. melanogaster ribosomes}

Results previously reported (Wen et al. 1974) indicated that genes for 5S RNA are present at six distinct loci in the polytene chromocsomes of G. barbipes. However, the 5S RNA used in these earlier hybridization experiments was prepared from a total RNA extract of $G$. barbipes, and the $5 \mathrm{~S}$ fraction was characterized only on criteria of size and capacity for hybridization to the $5 \mathrm{~S}$ genes of $D$. melanogaster. It is possible, therefore, that the 5S RNA in this preparation was contaminated with other RNAs of the same size class. If such RNA contaminants exist and are specific for $G$. barbipes, they would be undetected in D. melanogaster control hybridizations. Since it was essential, for the experiments reported here, to be certain that the sites previously identified were truly $5 \mathrm{~S}$ loci, we decided to confirm this by annealing 5S RNA from D. melanogaster ribosomes to G. barbipes salivary gland chromosomes.

RNA of D. melanogaster eluting from Sephadex G-100 in fractions 47-51 (Fig. 1) was pooled and a portion labelled with ${ }^{125} \mathrm{I}$ to localize the genes for $5 \mathrm{~S}$ RNA in $G$. barbipes. This RNA fraction was first characterized for size by gel electrophoresis. Figure 2 illustrates the electrophoretic profile of labelled $\left({ }^{125} \mathrm{I}\right)$ and unlabelled 5S RNA of D. melanogaster as well as authentic 4S and 5S RNA of 

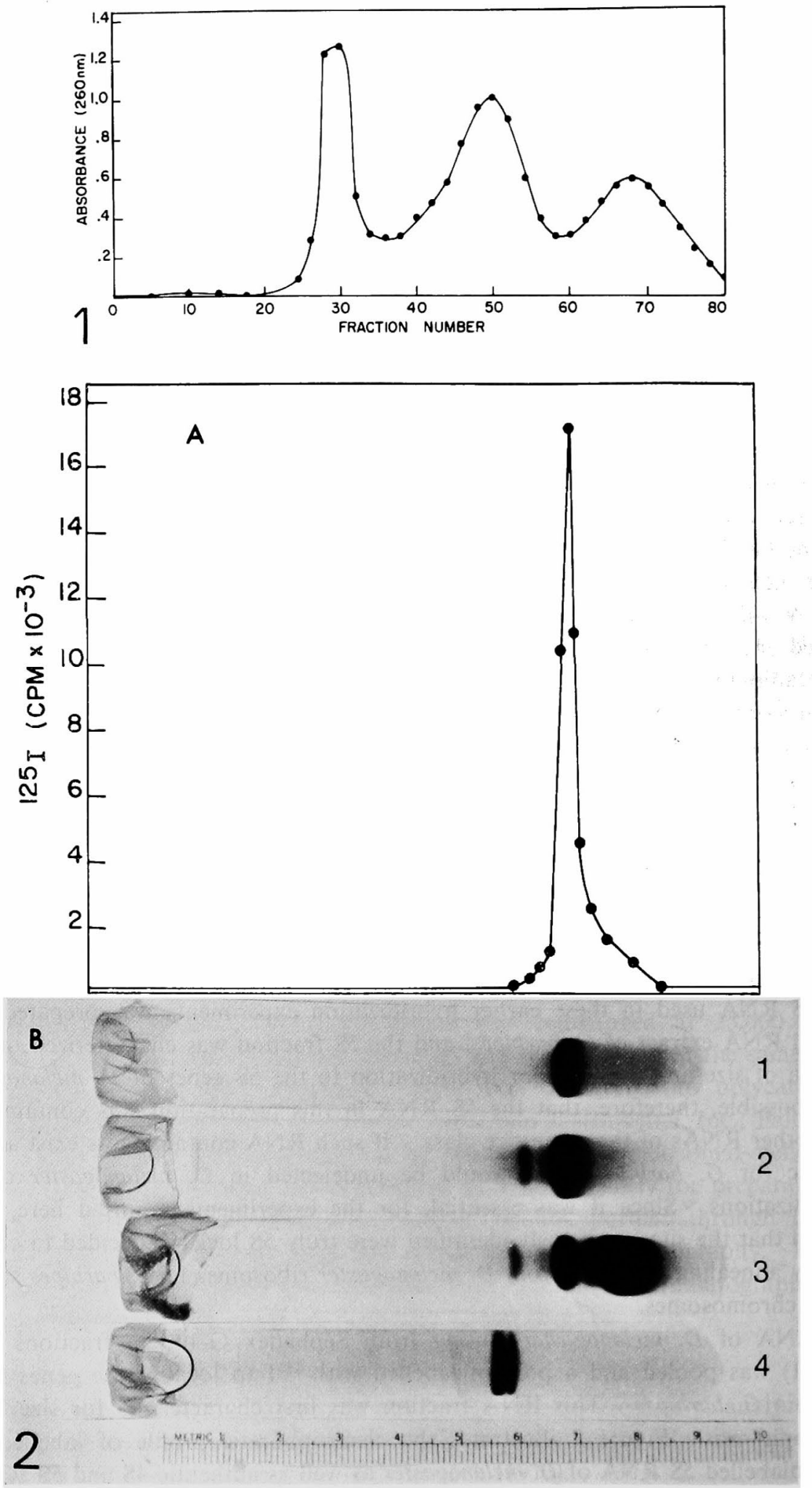
E. coli. It is demonstrated in Fig. 2A and the first gel in Fig. 2B that there is only one size class of $D$. melanogaster RNA in the pooled fraction. The maximum concentration of RNAs of other sizes in this fraction was estimated as less than $0.5 \%$. Since the RNA component of interest migrated, as does liver 5S RNA (Peacock and Dingman 1968), slightly behind the 5S of E. coli (gel 4, Fig. 2B), it was assumed to be the ribosomal 5S RNA species.

The putative 5S RNA was characterized for type by in situ hybridization. Figure 3 shows that the ${ }^{125}$ I-labelled RNA of the pooled fractions hybridized to the $56 \mathrm{~F}$ region and nucleolar organizer regions of $D$. melanogaster. The autoradiograph of Fig. 3 has been exposed for 29 days to prove the absence of radioactive RNAs hybridizing to other regions of the genome.

Annealing of radioactive 5S RNA in situ generally leads to the association of labelled molecules with nucleolus organizers as well as regions of the genome specific for authentic $5 \mathrm{~S}$ ribosomal RNA. It is likely that hybridization to the nucleolar region results from the presence of 5.8S RNA in our preparation, for $5.8 \mathrm{~S}$ RNA is also coded by the $18+28 \mathrm{~S}$ ribosomal RNA genes of the nucleolus organizer (Ritossa and Spiegelman 1965, Darnell 1968, Pene et al. 1968). 5S ribosomal RNA will not separate from 5.8S RNA on Sephadex G-100, but one might expect to observe such a contaminant after gel electrophoresis of the iodinated 5S fraction. As previously pointed out, this was not the case (Fig. 2A). However, on hybridization with 5S RNA, label associated with the nucleolar organizer appeared only after lengthy exposure periods. The extreme repetition of the genes for $28+18 \mathrm{~S}$ RNA may provide a very sensitive assay for the supposed $5.8 \mathrm{~S}$ fraction.

\section{Crytology of short arm of polytene chromosome III of G. barbipes and localization of SS RNA Genes}

Salivary gland chromosomes of $G$. barbipes have been studied previously by Basrur (1957), Meiseiko et al. (1971), Martin and Porter (1973), and Walter (1973). The short arm of chromosome III was designated as arm F by Martin and Porter (1973), and this designation is followed here. These same authors have characterized four sequences of this chromosome arm in populations from North America. We have identified these, as well as other sequences occurring less frequently, in the natural population from Yankton, S.D. (unpublished observations). Band sequences $\mathrm{F} 2$ and $\mathrm{F} 4$ differ from the $\mathrm{F} 1$ sequence by single inversion rearrangements and F3 is derived from F2 by simple chromosomal inversion also (Martin and Porter 1973). Regions illustrated by brackets around homozygous chromosomes of the $F 1 / F 1$ and F2/F2 sequences (Fig. 4) indicate inversions required to form the F3 and F4 sequences. The heterozygous F1/F2 sequence shown in Fig. 4 illustrates the

Figs. 1-2. 1, chromatography of $D$. melanogaster RNA on Sephadex G-100. $2.5 \mathrm{ml}$ fractions were collected and fractions 47-51 were pooled for analysis by gel electrophoresis and iodination. $2 \mathrm{~A}$ and B, gel electrophoresis of D. melanogaster RNA purified on Sephadex G-100. (A) Radicactivity profile of gel electrophoresis of ${ }^{128}$ I-labelled RNA (fractions 47-51, Fig. 1) illustrated in B-1 below. (B) Gel 1, co-electrophoresis of unlabelled and ${ }^{125}$ I-labelled Drosophila RNA; Gel 2, 5S RNA of E. coli (contaminated with an unknown RNA species); Gel 3, 4S and 5S RNA of E. coli; Gel 4, 5S RNA of E. coli and Drosophila RNA pool. Gel. 4 was not run simultaneously with the first three. 

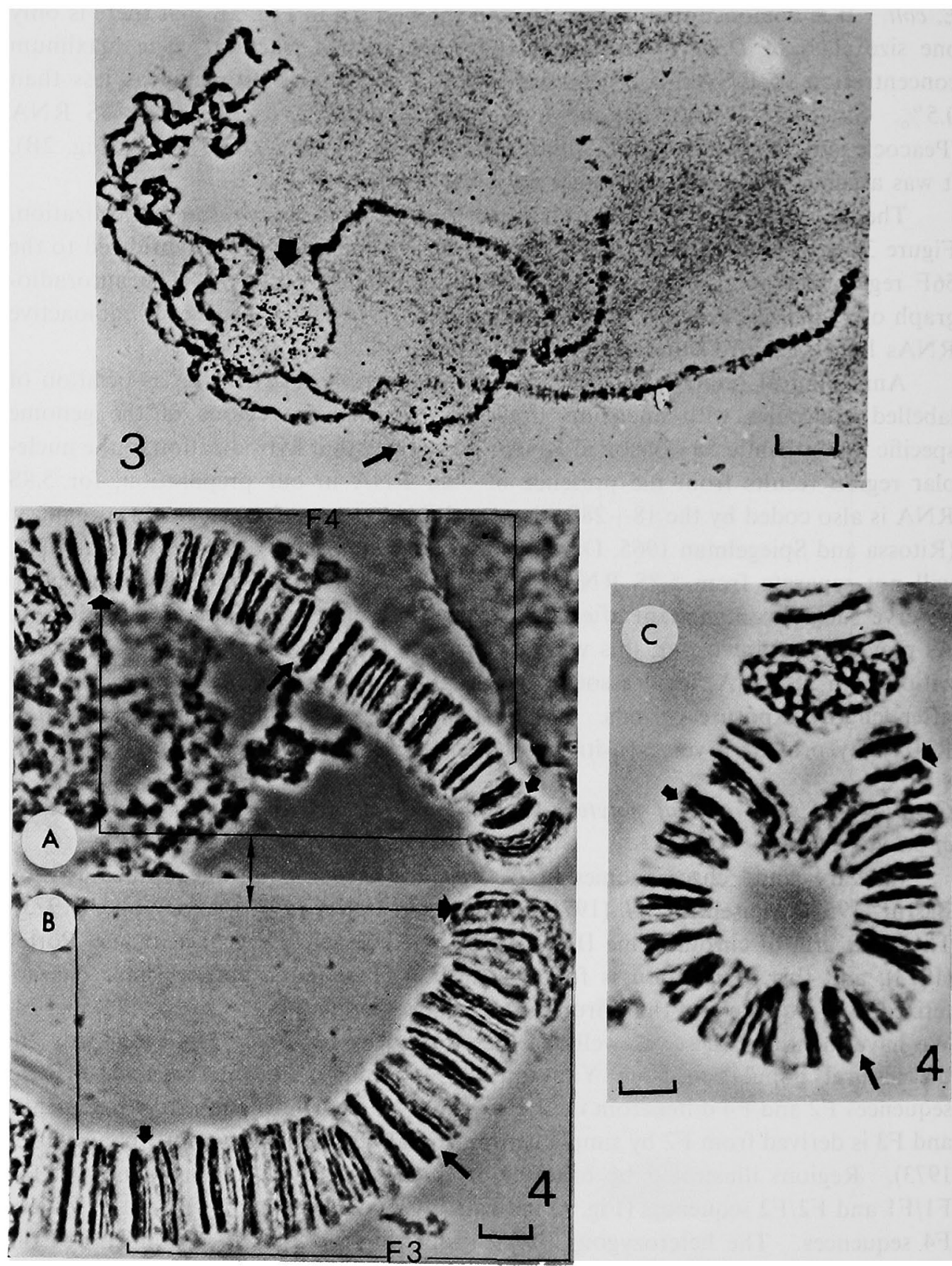

Figs. 3-4. 3, autoradiograph of D. melanogaster salivary chromosomes hybridized with ${ }^{125} \mathrm{I}$ labelled RNA fraction prepared from Drosophila ribosomes. Small arrow, labelling over band 56F; Large arrow, labelling over nucleolus. Exposure time 29 days. Bar $=20 \mu \mathrm{m}$. 4A-C, band sequences of chromosome arm F of G. barbipes. (A) F1/F1 homozygote. (B) F2/F2 homozygote. (C) F1/F2 heterozygote. Inversions are indicated by brackets above or below the chromosomes. F8a, ; F9o, $\uparrow$; and probably F11L, $\uparrow$ are the gene loci of 5S RNA. Bands F8a to F11v are paired in the heterozygote. $B a r=10 \mu \mathrm{m}$. 


\section{bands between F8a and F11V involved in the F1-F2 transformation.}

In our previous report (Wen et al. 1974), evidence of six loci for 5S RNA in the polytene chromosomes of G. barbipes was presented. However, in situ hybridi-

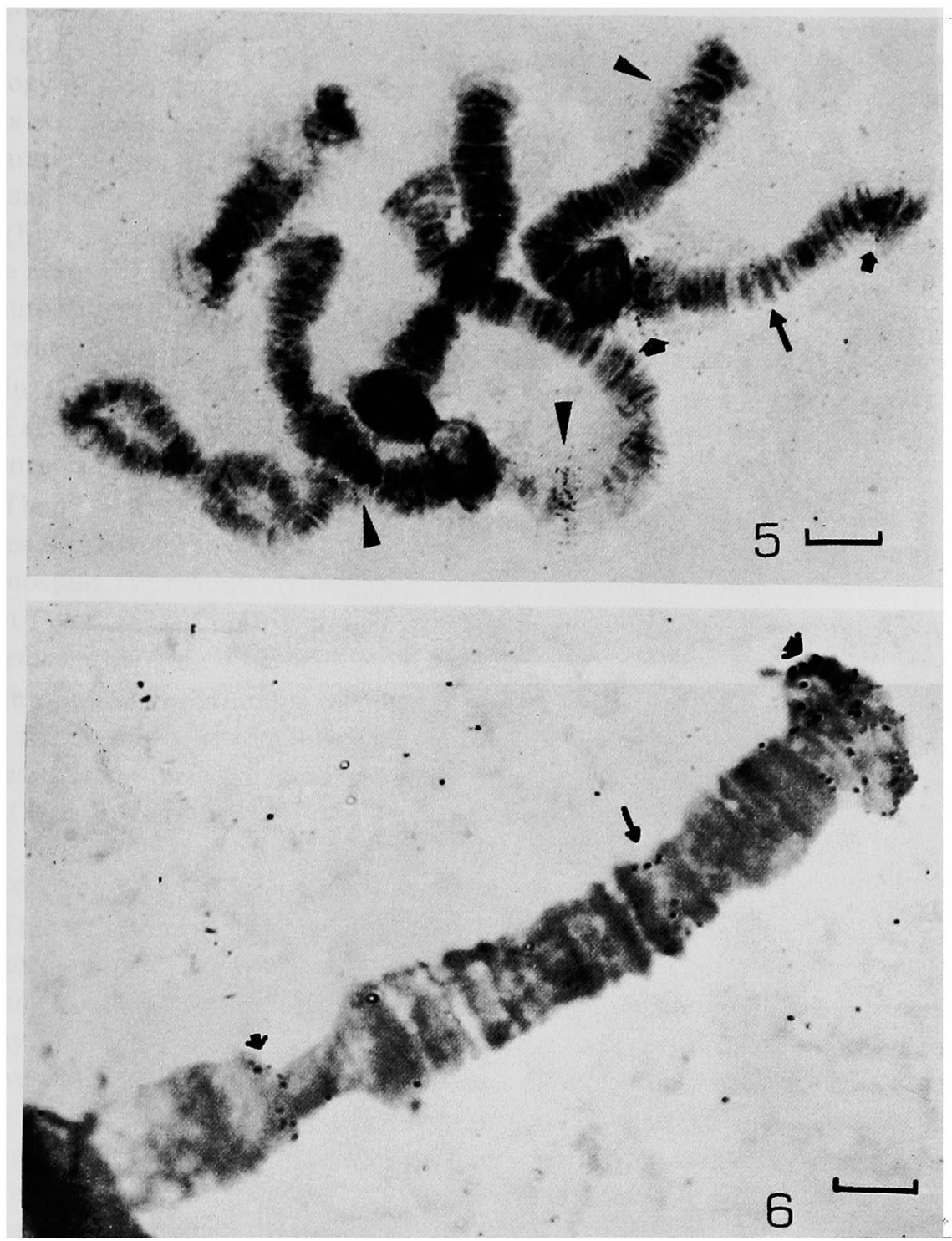

Figs. 5-6. 5, autoradiograph of G. barbipes chromosomes hybridized with ${ }^{125}$ I-labelled 5S RNA

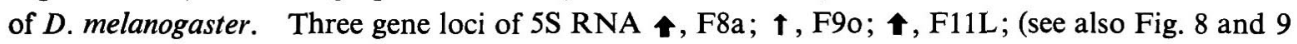
for band recognition) are labelled as well as three 18+28S RNA sites (triangles). Exposure time 20 days. Bar $\times 20 \mu$. 6, three gene loci for 5S RNA (F8a ; F9o $\uparrow ;$ F11L $\uparrow$ ) on the homozygous F2/F2 chromosomes of G. barbipes. Distal end of chromosomes (band F8a) is heavily labelled. Exposure time 15 days. $B a r=10 \mu \mathrm{m}$.

zation of $G$. barbipes chromosomes with ${ }^{125}$ I-labelled $D$. melanogaster RNA in the present study confirms only three of these sites (Fig. 5), and these are limited to the short arm of chromosome III. The position of these loci has been analyzed, and 

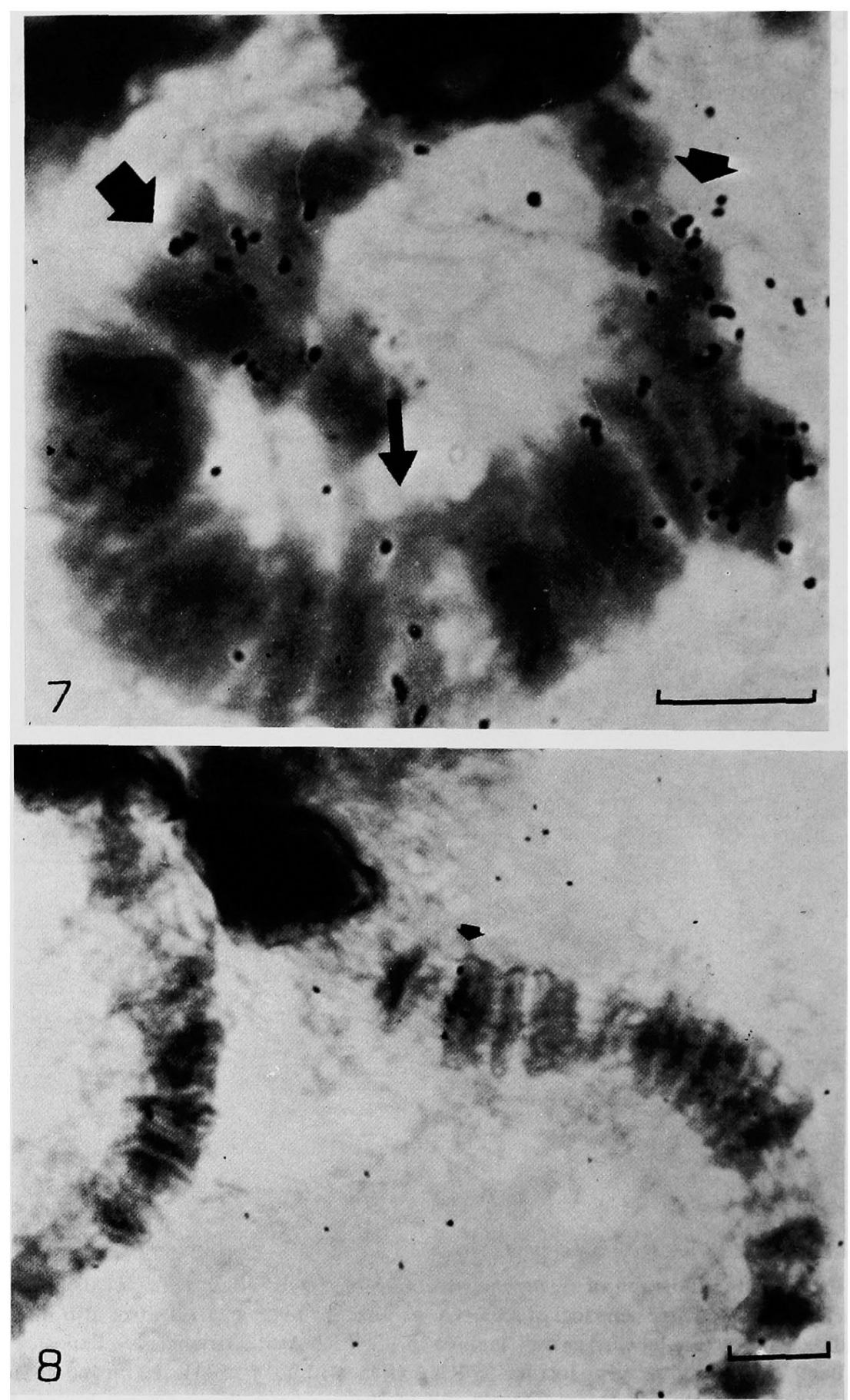

Figs. 7-8. 7, three gene loci (arrows) of 5S RNA on the heterozygous F1/F2 chromosomes of $G$. barbipes. Both homologous chromosomes above scale bar on the photograph are heavily labelled because of presence of band F8a (see Fig. 4C). Exposure time 25 days. Bar $=10 \mu \mathrm{m}$. 8 , the main gene locus for 5S RNA of $G$. barbipes on band F8a (arrow). Exposure time 80 hours. 
they are indicated as bands F8a, F9o, and probably F11L in Fig. 5. (See also Fig. 4 for band localization.) These three loci were demonstrated on the homozygous F1/F1 (Fig. 5) and F2/F2 (Fig. 6) sequences as well as the heterozygous F1/F2 sequences (Fig. 7). The gene locus at F8a is shown most clearly in Fig. 8, and the locus at F9o in Fig. 9. The third locus is tentatively assigned to F11L because the cytology of the preparations was not adequate for absolute correlation of the silver grains with the band. It was repeatedly observed in these polytene chromosome preparations that the number of silver grains accumulated over the $5 \mathrm{~S}$ gene loci was unequal, with the greatest number of grains over F8a and the least number over F9o (Figs. 5, 6 and 7). Since the number of silver grains is roughly proportional to the number of DNA sequences complementary to the labelled RNA (Szabo 1974), the autoradiographs indicate that most of the 5S RNA genes are located in band F8a, while band F9o contains the fewest copies of 5S RNA genes.

In Fig. 5 one may see that the three gene loci specific for $18+28 \mathrm{~S}$ RNA (Wen et al. 1974) are also labelled by the $5 \mathrm{~S}$ preparation. This again suggests the presence of 5.8S RNA in the $5 \mathrm{~S}$ iodinated fraction.

There is significant and consistent accumulation of silver grains only in the regions described above. Two loci on the long arm of chromosome II and one on chromosome IV, tentatively identified as 5S RNA transcription sites in our previous report (Wen et al. 1974), were not labelled by iodinated 5S ribosomal RNA from D. melanogaster.

In optimal preparations of inverted segments of the short arm of chromosome III, a fourth 5S locus was observed (Fig. 10). Analysis of the banding pattern indicates that the new 5S locus probably arises by a break within the F8a tandem repeat (see Discussion).

\section{Transcription of $5 S$ RNA on salivary gland chromosomes}

Transcription of $5 \mathrm{~S}$ genes in the salivary gland chromosomes of G. barbipes is not accompanied by distinct puffing of the bands, but it can be detected by labelling with ${ }^{3} \mathrm{H}$-uridine as described in Materials and methods. Autoradiography of the chromosomes after ${ }^{3} \mathrm{H}$-uridine uptake permits a comparison of the relative transcriptional activity at the several $5 \mathrm{~S}$ loci. Figures $11 \mathrm{~A}$ and $\mathrm{B}$ (chromosomes from the third and fourth instar stages) indicate that F8a, the locus containing the greatest number of 5S RNA gene sequences, is not labelled, while F9o, thought to contain the fewest gene copies, has probably incorporated some ${ }^{3} \mathrm{H}$ uridine. The site tentatively identified as F11L appears to be active also, but diffuse labelling in this area prevents certainty.

The same results were obtained when salivary glands were preincubated with low concentrations ( $5 \mu \mathrm{g} / \mathrm{ml}$ ) of $\alpha$-amanitin (Fig. 11C), a differential inhibitor of RNA polymerases (Egyhazi et al. 1972, Serfling et al. 1972). In the presence of this low concentration of inhibitor the total label associated with the chromosomes is greatly reduced as indicated by the lower number of silver grains over Balbiani rings on chromosome IV (unpublished observation). Polymerases transcribing heterogeneous RNA appear to be most sensitive to $\alpha$-amanitin as evidenced by studies in Chironomus (Egyhazi et al. 1972, Serfling et al. 1972), while polymerases 


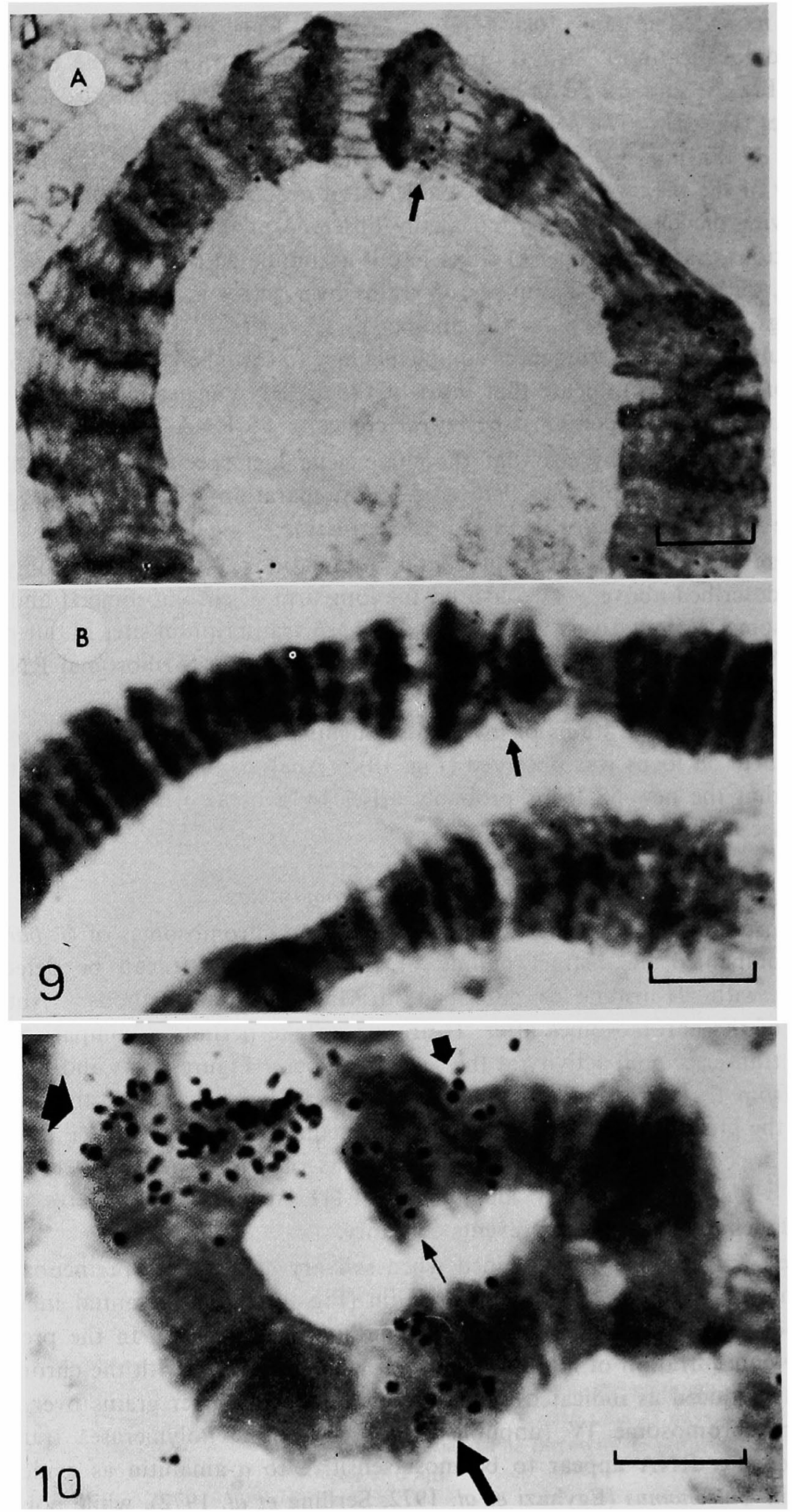


transcribing 1) transfer RNA and 5S RNA and 2) $18+28$ S RNA are less susceptible (Weinman and Roeder 1974). This appears to be in keeping with the results found here. When the concentration of inhibitor is increased to $100 \mu \mathrm{g} / \mathrm{ml}$, subsequent autoradiographic analysis of the $5 \mathrm{~S}$ sites indicates that these are inactivated. This is demonstrated in Fig. 12, an autoradiograph from a third instar

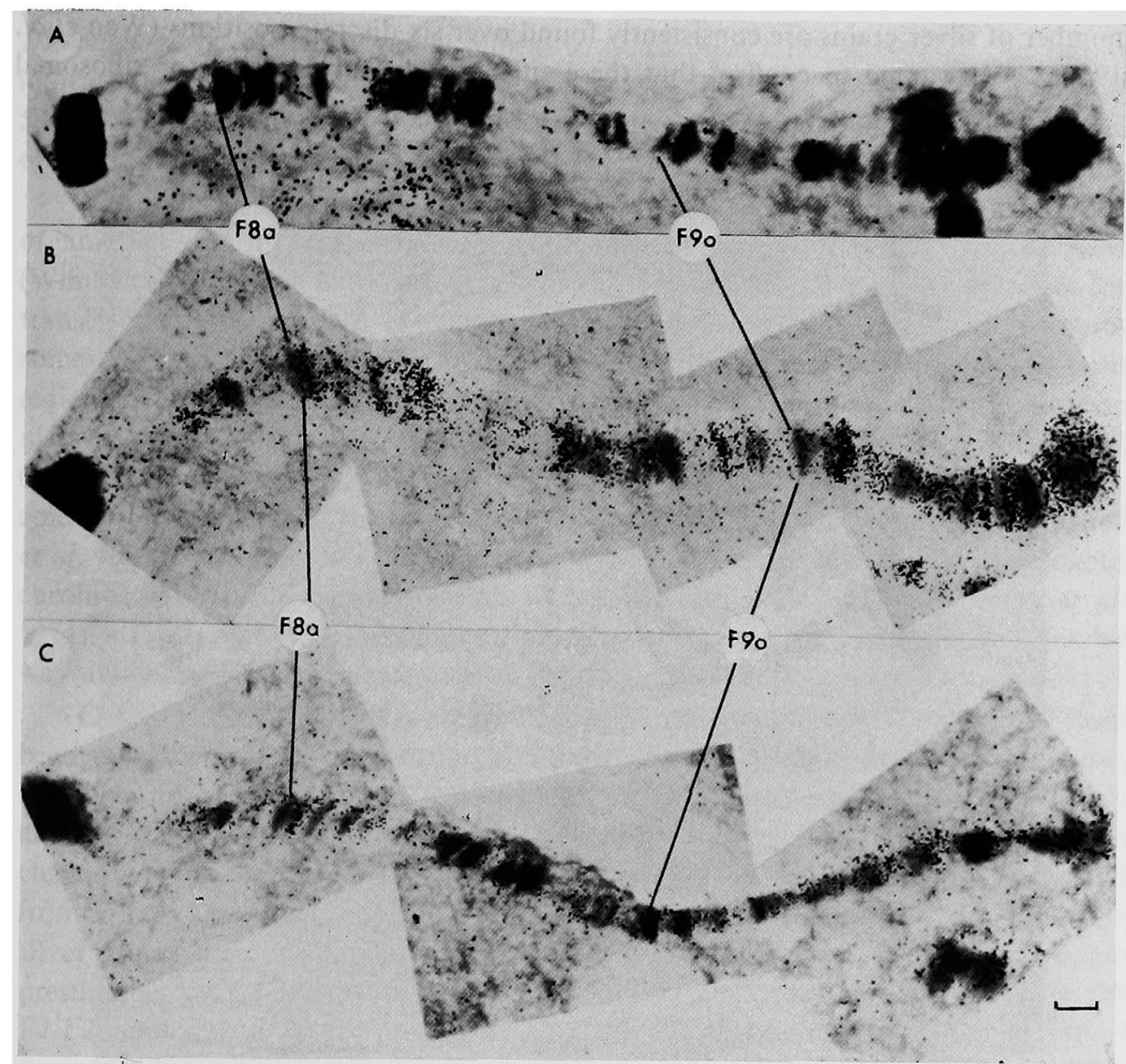

Fig. 11A-C. Autoradiographs of arm F of polytene chromosomes from third (A) and fourth (B and $C$ ) larval instar labelled with tritiated uridine in the presence $(C)$ or absence (A andB) of of $5 \mu \mathrm{g} / \mathrm{ml} \alpha$-amanitin. Exposure time: A, $42 \mathrm{hr} ; \mathrm{B}, 48 \mathrm{hr} ; \mathrm{C}, 86 \mathrm{hr}$.

larva prepared under the same experimental conditions as that used for the low concentration $\alpha$-amanitin experiments (Fig. 11). Only the three 18+28S RNA sites have conspicuously incorporated label at the high inhibitor levels (Fig. 12). Polymerases transcribing large ribosomal RNAs have been shown to be most

Figs. 9-10. 9A and B, gene locus of 5S RNA of G. barbipes at F9o (arrow). (A) Exposure time 67 hours. (B) Exposure time 29 days. Bar $=10 \mu \mathrm{m}$. 10, demonstration of four 5S RNA sites on arm $\mathrm{F}$ of $G$. barbipes in the F1/F2 configuration (arrows). Exposure time is 25 days. In Fig. 8 of our previous communication (Wen, et al. 1974), these four sites are also displayed on arm $F$ of the F1/F1 configuration. $B a r=10 \mu \mathrm{m}$. 
resistant to $\alpha$-amanitin (Weinman and Roeder 1974).

\section{Discussion}

When 5S RNA is purified from total RNA extracted from G. barbipes, iodinated with ${ }^{123}$ I and annealed to the polytene chromosomes of this organism, a significant number of silver grains are consistently found over six discrete positions (Wen $e t$ al. 1974). We wanted to confirm that these sites are all truly specific for ribosomal

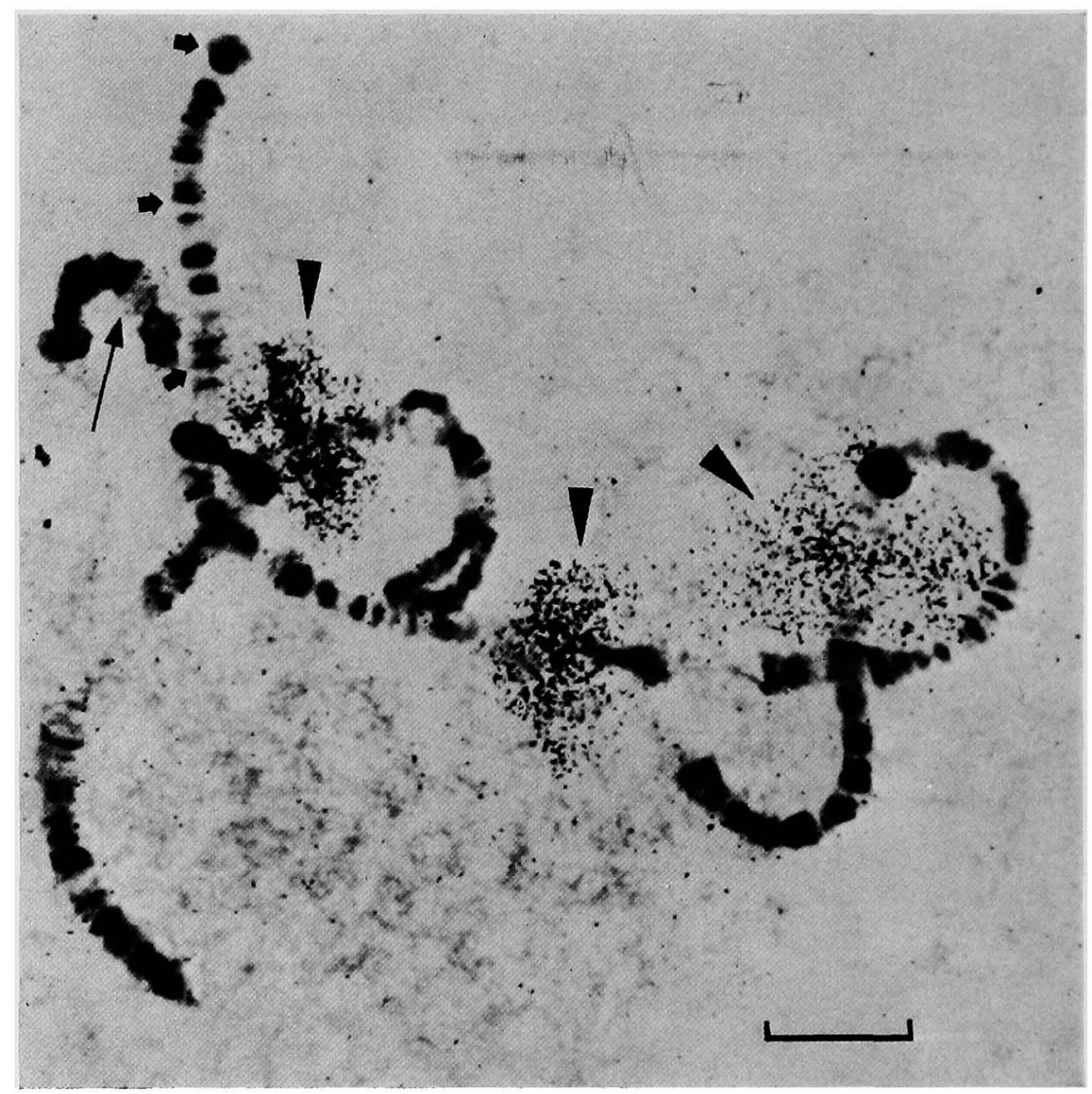

Fig. 12. Autoradiograph of polytene chromosomes from third larval instar labelled with ${ }^{3} \mathrm{H}-$ urdine in presence of $\alpha$-amanitin $(100 \mu \mathrm{g} / \mathrm{ml})$. Three $18+28 S$ RNA sites are labelled (triangles), whereas genes coding for 5S RNA (short arrows) as well as genes in Balbiani ring (long arrow) are not. Exposure time $72 \mathrm{hrs}$. Bar $=10 \mu \mathrm{m}$.

5S RNA. Since it is difficult to purify any nucleic acid fraction to homogeneity, it is possible that the $G$. barbipes 5S RNA contained a contaminant of similar molecular size. If such contaminating molecules are transcribed from repetitive sequences unique to the G. barbipes genome, they would not hybridize to chromosomes of the control organism but would anneal to chromosomes of G. barbipes. Such an occurrence would lead to erroneous identification of labelled sites as $5 \mathrm{~S}$ loci. 
It has been shown that the genes of 5S RNA are conserved during evolution, for the nucleotide sequences of 5S RNAs isolated from different Orders are very similar (Payne et al. 1973, Sanhoff et al. 1973). We thought a most exacting way to verify the alleged $5 \mathrm{~S}$ loci was to challenge $G$. barbipes chromosomes with $5 \mathrm{~S}$ RNA prepared from $D$. melanogaster ribosomes. G. barbipes and D. melanogaster are both in the Order Diptera and are expected to have similar sequences for 5S RNA. Furthermore, it seemed unlikely that any contaminating RNA molecules in the $D$. melanogaster 5S RNA would anneal to $G$. barbipes chromosomes. Our results indicate that only three of the six previously identified sites are verifiable as loci of 5S RNA transcription. These three true 5S loci are all confined to the short arm of chromosome III: F8a, F9o and, tentatively, F11L.

Multiple gene loci for 5S RNA are common but not universal among eucaryotic organisms. For example, Rhynchosciara angelae (Szabo et al. 1972), Zea mays (Wimber et al. 1974) and Taricha granulosa (Leon 1976) have only single loci for transcription of 5S RNA. Exchange of DNA between non-homologous chromosomes is a possible mechanism by which repeated genes may be spread to different regions of the genome. For example, in $X$. laevis during zygotene of spermatocyte meiosis all the genes for 5S RNA form a tight cluster on one side of the nucleus ("bouquet conformation"), and it has been suggested that exchange of 5S RNA could occur between all the chromosomes as meiotic crossing-over proceeds (Pardue et al. 1973). In polytene chromosomes of $G$. barbipes, rDNA of non-homologous chromosomes forms chromatin bridges between nucleolar organizers (Wen et al. 1974). This suggests that meiotic or mitotic chromosomes may behave in a similar way and lead of exchange of genetic material.

Chromosomal inversions are of common occurrence in the Diptera and have been well documented in different species of Drosophila (Novitski 1946), Tendipes (Tothfels and Fairlie 1957), Glyptotendipes (Fig. 4), etc. Inversions may provide another way for spreading repetitive DNA sequences and producing multiple gene clusters on the chromosome. In Fig. 4, band F8a is seen to be slightly separated from F8b. This band separation is not observable in Fig. 8, but in this figure the silver grains have accumulated only on the proximal side of the observed band, presumably over F8a. Although the labelling of the distal 5S gene cluster in the F2/F2 homozygote is always diffuse (Fig. 6), the banding pattern seen in Fig. 4 shows that F8a is included in the inverted region of the F2/F2 chromosome. This observation implies that it is band F8a which is labelled. This was confirmed by in situ hybridization of ${ }^{125}$ I-labelled RNA to F1/F2 heterozygotes. In this case, labelling of F8a is observed on both of the paired homologous chromosomes (Fig. 7). When F8a moves from the distal to the proximal position of arm $F$, by chromosomal inversion involving bands F8a through F11v (F2 $\rightarrow F 1$ conversion), four gene loci on arm F are labelled with 5S RNA prepared from either G. barbipes or D. melanogaster (Fig. 10). This suggests that one of the tandemly-repeated sequences for $5 \mathrm{~S}$ on arm $\mathrm{F}$ has been cleaved within the repeated region, resulting in an additional locus after inversion. It is tempting to speculate that all three gene loci of 5S RNA on arm F may have been generated in a similar way from a primordial locus. 
It has been demonstrated (Fig. 11) that 5S locus F8a is not labelled with tritiated uridine. This indicates that the synthesis of 5S RNA at this site is too slow to be detected under the conditions of the experiment. However, there is rapid synthesis of $18+28 \mathrm{~S}$ RNA on the same chromosomes during this period as indicated by the large number of silver grains covering the three rDNA sites (unpublished observation). In ribosomes, $18+28 \mathrm{~S}$ RNA and 5S RNA occur in a one: one ratio, and one might expect, contrary to the evidence, that the 5S locus at F8a would be active, for this is probably the largest $5 \mathrm{~S}$ cluster in this organism. However, there are several cases in which non-coordinate synthesis of $5 \mathrm{~S}$ and $18+$ 28S RNA has been observed (Ford 1971, Weinmann 1972). Two possible interpretations for the slow rate of $5 \mathrm{~S}$ synthesis in G. barbipes salivary glands are: 1) There exists a pool of 5S RNA in the salivary gland which makes in unnecessary to transcribe these molecules at a rapid rate for ribosome assembly; and 2) there are more copies of 5S RNA than rRNA in the salivary glands, and a relatively slow rate of 5S RNA synthesis in F8a is sufficient to satisfy the required one: one stoichiometry of products.

The ratio of $5 \mathrm{~S}$ to $18+28 \mathrm{~S}$ RNA genes can be increased during polytenization. For example, in the salivary gland polytene chromosomes of $D$. melanogaster, rDNA is under-replicated relative to euchromatic DNA (Spear and Gall 1973). In fact, even in diploid tissues there may be more copies of genes for 5S RNA than rRNA. Such is the case in Xenopus (Brown and Weber 1968), and in Hela cells (Hatlen and Attardi 1971). Further, in X. laevis only 3\% of the total $5 \mathrm{~S}$ genes of somatic cells are active in RNA transcription (Brownless et al. 1974). Therefore, in this organisms also, genes for 5S RNA appear to be subject to differential transcriptional control.

Genes coding for rRNA commonly undergo intensive extrachromosomal replication or amplification during oogenesis (Brown and David 1968, Gall 1968, Gall and Rochaix 1974). On subsequent synthesis of rRNA from these genes, it may be necessary to have "extra" copies of the $5 \mathrm{~S}$ genes on the chromosomes themselves for coordinate synthesis and assembly of ribosomes. After this period of rapid synthesis, further transcription may be terminated at many of the $5 \mathrm{~S}$ genes. It would be of interest to determine if $5 \mathrm{~S}$ genes on F8a are active in other tissue of this organism.

In further work it is also important to analyze the nucleotide sequence of $5 \mathrm{~S}$ RNA from the salivary gland and other tissues of G. barbipes. If more than one sequence of 5S RNA is indicated by fingerprint analysis, the occurrence of several loci would lead one to suspect that each locus may be specific for a particular sequence. With such an arrangement, the expression of all genes could be regulated by a simple mechanism such as that suggested by Ford and Southern (1973). On the other hand, if the multiple $5 \mathrm{~S}$ clusters originated by breakage within tandem gene repeats and subsequent inversion, the suggestion that the several loci have distinct DNA sequences becomes less compelling. Of course, gene mutation at the several sites might have altered these distinct loci even after the inversion events. 


\begin{abstract}
Three loci transcribing 5S RNA have been verified on the short arm of chromosome III of $G$. barbipes. Evidence is also presented which indicates that a fourth site may arise on this same arm by chromosomal inversion following a break within the major 5S locus. Autoradiography after ${ }^{3} \mathrm{H}$-uridine incorporation indicates that the major $5 \mathrm{~S}$ locus on chromosome III is relatively inactive in transcription in nuclei of salivary gland cells while the minor sites actively transcribe 5S RNA.
\end{abstract}

\title{
Acknowledgements
}

The report presented here comprised part of the Ph.D. thesis presented to the University of Oregon by Wu-Nan Wen. This research was supported by U.S. Public Health Service research grants GM19205 to D. R. Hague and GM18829 to D. Wimber. We warmly appreciate and acknowledge our collaboration with Dr. D. Wimber throughout the course of these studies.

\section{References}

Basrur, V. R. 1957. Inversion polymorphism in the midge Glyptotendipes barbipes (Staeger). Chromosoma (Berl.) 8: 597-608.

Brown, D. D. and David, I. B. 1968. Specific gene amplification in oocytes. Science 160: 272280.

— and Weber, C. S. 1968. Gene linkage by RNA-DNA hybridization. I. Unique DNA sequences homologous to 4S RNA and ribosomal RNA. J. Mol. Biol. 34: 661-680.

Brownlee, G. G., Cartwright, E. M. and Brown, D. D. 1974. Sequence studies of the 5S DNA of Xenopus laevis. J. Mol. Biol. 89: 703-718.

-, Cartwright, E. M., McShane, T. and Williamson, T. 1972. The nucleotide sequence of somatic 5S RNA from Xenopus laevis. FEBS Lett. 25: 8-12.

Darnell, J. E. Jr. 1968. Ribonucleic acids from small cells. Bacteriol. Rev. 32: 262-290.

Dingman, C.W. and Peacock, A. C. 1973. Polyacrylamide gel elctrophoresis of RNA. In: Procedures in Nucleic Acid Research, 2: 623-628 (G. L. Cantoni and D. R. Davies, eds.), Harper \& Row, N. Y.

Egyhazi, E., D'monte, B. and Edstrom, J.-E. 1972. Effects of $\alpha$-amanitin on in vitro labelling of RNA from defined nuclear components in salivary gland cells from Chironomus tentans. J, Cell Biol. 53: 523-531.

Ford, P. J. 1971. Non-coordinated accumulation and synthesis of $5 \mathrm{~S}$ ribonucleic acid by ovaries of Xenopus laevis. Nature (Lond.) 233: 561-564.

Ford, P. J. and Southern, E. M. 1973. Different sequences for 5S RNA in kidney cells and ovaries of Xenopus laevis. Nature (Lond.) New Biol. 241: 7-12.

Gall, J. G. 1968. Differential synthesis of the gene for ribosomal RNA during amphibian oogenesis. Proc. Nat. Acad. Sci. (Wash.) 60: 553-560.

- and Pardue, M. L. 1969. Formation and detection of RNA-DNA hybrid molecules in cytological preparation. Proc. Nat. Acad. Sci. (Wash.) 63: 378-383.

- and Rochaix, J.-D. 1974. The amplified ribosomal DNA of Dytiscid beetles. Proc. Nat. Acad. Sci. (Wash.) 71: 1819-1823.

Hatlen, L. and Attardi, G. 1971. Proportion of the Hela genome complementary to transfer RNA and 5S RNA. J. Mol. Biol. 56: 535-553.

Hutchison, N. and Pardue, M. L. 1975. The mitotic chromosomes of Notophthalmus (=Triturus) 
viridescens. Localization of $\mathrm{c}$ banding regions and DNA sequences complementary to 18S, 28S, and 5S ribosomal RNA. Chromosoma (Berl.) 53: 51-69.

Johnson, L. P., Henderson, A. L. and Atwood, K. C. (1974). Location of the genes for 5S RNA in the human chromosome complement. In: New Haven Conference (1973), First International Workshop in Human Gene Mapping. Birth Defects: Original article series X: 3 (D. Gergema, ed.), pp. 103-105, New York, The National Foundation.

Leon, P. E. 1976. Molecular hybridization of iodinated 4S, 5S and 18+28S RNA to salamander chromosomes. J. Cell Biol. 69: 287-300.

Martin, J. and Porter, D. L. 1973. The salivary gland chromosomes of Glyptotendipes aarbipes (Staeger) (Diptera, Chrionomidae): Description of inversions and comparison of Nearctic and Palearctic karyotypes. Studies in natural Sciences, Vol. 1,No. 7, 25 pp. Published by the Natural Science Research Institute, Eastern New Mexico University, Portales, N. M., U.S.A.

Miseiko, G. N., Minsarinova, B. Kh. and Kiknadze, I. I. 1971. The karyotype structure in natural populations of Glyptotendipes barbipes (Diptera, Chrionomidae) (in Russian). Tsitologzia 13: 1501-1505.

Monier, R. 1973. Preparation and properties of Escherichia coli 5S RNA. In: Procedures in Nucleic Acid Research, 2, 618-622 (G. L. Cantoni and D. R. Davies, eds), Harper \& Row, N. Y.

Novitski, E. 1946. Chromosome variation in Drosophila athabasca. Genetics 31: 508-524.

Pardue, M. L., Brown, D. D. and Birnstiel, M. L. 1973. Location of the genes for 5 S ribosomal RNA in Xenopus laevis. Chromosoma (Berl.) 42: 191-203.

Payne, P. I., Corry, M. J. and Dyer, T. A. 1973. Nucleotide sequence analysis of the cytoplasmic 5S ribosomal ribonucleic acid from five species of flowering plants. Biochem. J. 135: 845-851.

Peacock, A. C. and Dingman, C.W. 1968. Molecular weight estimation and separation of ribonucleic acid by electrophoresis in agarose-acrylamide composite gels. Biochem. 7: 668-674.

Pelley, J. W. and Stafford, D. W. 1970. Partial purification of the aminoacyl-tRNA binding enzyme from Drosophila larvae. Biochim. Biophys. Acta 204: 400-405.

Pene, J. J., Knight, E. and Darnell, J. E. 1968. Characterization of a new low molecular weight RNA in Hela cell ribosomes. J. Mol. Biol. 33: 609-623.

Pukkila, P. J. 1975. Identification of the lampbrush chromosome loops which transcribe 5S ribosomal RNA in Notophthalmus (Triturus) viridescens. Chromosoma (Berl.) 53: 71-89.

Ritossa, F. M. and Spiegelman, S. 1965. Localization of DNA complementary to ribosomal RNA in the nucleolus organizer of Drosophila melanogaster. Proc. Nat. Acad. Sci. (Wash.) 53: 737-745.

Robert, M. 1971. Einfluss von Ionenstärke und $\mathrm{pH}$ auf die differentielle Dekondensation der Nukleoproteide isolierter Speicheldrüsen-Zellkerne und Chromosomen von Chrinomus thumi. Chromosoma (Berl.) 36: 1-33.

Rothfels, K. H. and Fairlie, T. W. 1957. The non-random distribution of inversion breaks in the midge Tendipes decorus. Can. J. Zool. 35: 221-263.

Sanhoff, D., Morel, C. and Cedergren, R. J. 1973. Evolution of 5S RNA and the non-randomness of base replacement. Nature (Lond.) New Biol, 245: 232-234.

Serfling, E., Wobus, U. and Panitz, R. 1972. Effect of $\alpha$-amanitin on chromosomal and nucleolar RNA-synthesis in Chironomus thummi polytene chromosomes. FEBS Lett. 20: 148-152.

Spear, B. B. and Gall, J. G. 1973 . Independent control of ribosomal gene replication in polytene chromosomes of Drosophila melanogaster. Proc. Nat. Acad. Sci. (Wash.) 70: 13591363.

Steffensen, D. M., Duffey, P. and Prensky, W. 1974. Localization of 5S ribosomal RNA genes on human chromosomes. Nature (Lond.) 252: 741-743.

Szabo, P. 1974. The localization of genes: Studies with in situ hybridization. Ph.D. Thesis, University of Illinois.

-, Steffensen, D. M. and Parvan, L. 1972. Unpublished observations cited by Wimber et al. 
in Chromosoma (Berl.) 47: 353-359.

Tartof, K. D. and Perry, R. 1970. The 5S RNA genes of Drosophila melanogaster. J. Mol. Biol. 51 : 171-183.

Walter, L. 1973. Syntheseprozesse an den Riesenchromosomen von Glyptotendipes. Chromosoma (Berl.) 41: 327-360.

Wegnez, M., Monier, R. and Denis, H. 1972. Sequence heterogeneity of 5S RNA in Xenopus laevis. FEBS Lett. 25: 13-20.

Weinmann, R. 1972. Regulation of ribosomal RNA and 5S RNA synthesis in Drosophila melanogaster I. Bobbed mutants. Genetics 72: 267-276.

- and Roeder, R. G. 1974. Role of DNA-dependent RNA polymerase III in the transcription of the tRNA and 5S RNA gens. Proc. Nat. Acad. Sci. (Wash.) 71: 1790-1794.

Wen, W.-N., Leon, P. E. and Hague, D. R. 1974. Multiple gene sites for 5S and 18+28S RNA on chromosomes of Glyptotendipes barbipes (Staeger). J. Cell Biol. 62: 132-144.

Wieslander, L., Lambert, B. and Egyhazi, E. 1975. Localization of 5S RNA genes in Chironomus tentans. Chromosoma (Berl.): 49-56.

Wimber, D. E., Duffey, P. E., Steffensen, D. M. and Prensky, W. 1974. Localization of the 5S RNA genes in Zea mays by RNA-DNA hybridization in situ. Chromosoma (Berl.) 47: 353-359.

- and Steffensen, D. M. 1970. Localization of 5S genes on Drosopihla chromosomes by RNADNA hybridization. Science 170: 639-641. 